AperTO - Archivio Istituzionale Open Access dell'Università di Torino

\title{
Halide substitution in magnesium borohydride
}

\section{This is the author's manuscript}

Original Citation:

Availability:

This version is available http://hdl.handle.net/2318/105908

since 2016-08-20T16:11:30Z

Published version:

DOI:10.1021/jp303123q

Terms of use:

Open Access

Anyone can freely access the full text of works made available as "Open Access". Works made available under a Creative Commons license can be used according to the terms and conditions of said license. Use of all other works requires consent of the right holder (author or publisher) if not exempted from copyright protection by the applicable law. 
This is the author's final version of the contribution published as:

Satoshi Hino; Jon Erling Fonneløp; Marta Corno; Olena Zavorotynska; Alessandro Damin; Bo Richter; Marcello Baricco; Torben R. Jensen; Magnus H. Sørby; Bjørn C. Hauback. Halide substitution in magnesium borohydride. JOURNAL OF PHYSICAL CHEMISTRY. C, NANOMATERIALS AND INTERFACES. 116 (23) pp: 12482-12488.

DOI: $10.1021 /$ jp303123q

The publisher's version is available at:

http://pubs.acs.org/doi/abs/10.1021/jp303123q

When citing, please refer to the published version.

Link to this full text:

http://hdl.handle.net/2318/105908 


\title{
Halide Substitution in Magnesium Borohydride
}

\author{
Satoshi Hino, ${ }^{*}{ }^{\dagger}$ Jon Erling Fonneløp, ${ }^{\dagger}$ Marta Corno, ${ }^{\ddagger}$ Olena Zavorotynska, ${ }^{\ddagger}$ Alessandro Damin,${ }^{\ddagger}$ Bo \\ Richter, ${ }^{\S}$ Marcello Baricco, ${ }^{\ddagger}$ Torben R. Jensen, ${ }^{\S}$ Magnus H. Sørby, ${ }^{*}{ }^{\dagger}$ and Bjørn C. Hauback ${ }^{\dagger}$ \\ ${ }_{\dagger}^{\dagger}$ Physics Department, Institute for Energy Technology, P.O. Box 40, NO-2027 Kjeller, Norway \\ Dipartimento di Chimica IFM and NIS, Universitàdi Torino, Torino, Italy \\ ${ }^{\S}$ Center for Materials Crystallography, Interdisciplinary Nanoscience Center and Department of \\ Chemistry, Aarhus University, Langelandsgade 140, DK-8000 Aarhus C, Denmark
}

\begin{abstract}
The synthesis of halide-substituted $\mathrm{Mg}\left(\mathrm{BH}_{4}\right)_{2}$ by ball-milling, and characterization with respect to thermodynamics and crystal structure, has been addressed. The ball-milled mixture of $\mathrm{Mg}\left(\mathrm{BH}_{4}\right)_{2}$ and $\mathrm{MgX}_{2}(\mathrm{X}=\mathrm{Cl}, \mathrm{Br})$ has been investigated by in situ/ex situ synchrotron powder X-ray diffraction (SR-PXD), differential scanning calorimetry (DSC), and infrared and Raman spectroscopy. High resolution SR-PXD patterns reveal that the unit cell volume of $\beta-\mathrm{Mg}\left(\mathrm{BH}_{4}\right)_{2}$ in milled and annealed mixtures of $\mathrm{Mg}\left(\mathrm{BH}_{4}\right)_{2}$ with $\mathrm{MgCl}_{2} / \mathrm{MgBr}_{2}$ is smaller than that of pure $\beta-\mathrm{Mg}\left(\mathrm{BH}_{4}\right)_{2}$. This is due to substitution of $\mathrm{BH}_{4}^{-}$by $\mathrm{Cl}^{-} / \mathrm{Br}^{-}$ions which have ionic radii smaller than that of $\mathrm{BH}_{4}{ }^{-}$. For comparison, ab initio calculations were run to simulate $\mathrm{Cl}$ substitution in $\alpha-\mathrm{Mg}\left(\mathrm{BH}_{4}\right)_{2}$. The $\alpha$-polymorph was used rather than the $\beta$-polymorph because the size of the unit cell was more manageable. Electronic energy data and thermodynamic considerations confirm the miscibility of $\mathrm{MgCl}_{2}$ and $\mathrm{Mg}\left(\mathrm{BH}_{4}\right)_{2}$, both in $\alpha$ - and $\beta$ polymorphs.
\end{abstract}

\section{INTRODUCTION}

Alkali and alkaline earth metal borohydrides are in focus as hydrogen storage materials due to their high gravimetric hydrogen capacity. ${ }^{1-5}$ However, $\mathrm{LiBH}_{4}$ and $\mathrm{NaBH}_{4}$ need high temperature for hydrogen desorption because of their high thermodynamic stability. $\mathrm{Mg}\left(\mathrm{BH}_{4}\right)_{2}$ and $\mathrm{Ca}\left(\mathrm{BH}_{4}\right)_{2}$ have more favorable thermodynamic properties, though poor kinetics prevent these compounds from desorbing hydrogen at moderate temperatures. For instance, $\mathrm{Mg}\left(\mathrm{BH}_{4}\right)_{2}$ holds $14.9 \mathrm{wt} \%$ hydrogen and has a volumetric hydrogen density of $147.4 \mathrm{~kg} \mathrm{H} \cdot \mathrm{m}^{-3}$. The enthalpy change of the following hydrogen desorption reaction (Scheme 1) is $25 \mathrm{~kJ} \cdot\left(\mathrm{mol} \mathrm{H}_{2}\right)^{-1}$, which would correspond to hydrogen desorption/absorption at moderate temperatures. ${ }^{6}$

$$
\mathrm{Mg}\left(\mathrm{BH}_{4}\right)_{2} \rightarrow \mathrm{MgH}_{2}+2 \mathrm{~B}+3 \mathrm{H}_{2}
$$

To modify the hydrogen storage properties of borohydrides, different approaches have been tried. Additions of other compounds to form composites can stabilize the dehydro-genated state and reduce hydrogenation enthalpy. ${ }^{9}$ Partial substitution of a metal with low electronegativity (e.g., Li, Na, K) by a more electronegative metal (e.g., $\mathrm{Zn}, \mathrm{Ti}, \mathrm{Mn}, \mathrm{Zr}, \mathrm{Mg}$ ) may allow the tuning of the thermodynamic properties of borohydrides. ${ }^{10}$ Use of suitable catalysts can improve hydrogen desorption/absorption kinetics. ${ }^{11}$ Recently, confinements in nanoporous scaffolds have also been investigated.

Partial substitution of an element or ion, i.e., hydrogen, with a more electronegative element changes the bond strength of the remaining elements, and it may facilitate release of hydrogen at more moderate conditions. For instance, partial substitution of fluorine for hydrogen in $\mathrm{NaAlH}_{4}$ has been shown to have a substantial effect on the hydrogen sorption properties. ${ }^{14} \mathrm{~A}$ similar approach has been attempted for However, experimental studies ${ }^{7,8}$ show that temperatures of more than $300{ }^{\circ} \mathrm{C}$ are needed for decomposition because of the sluggish kinetics. borohydrides where $\mathrm{H}$ inside the $\mathrm{BH}_{4}{ }^{-}$ions may be substituted by $\mathrm{F}$ or entire $\mathrm{BH}_{4}{ }^{-}$ions may be substituted by larger halides. ${ }^{15-20}$ However, some studies have reported that substitution results in 
stabilization of the hydrogenated state. For instance, for the $\mathrm{LiBH}_{4}-\mathrm{LiI}$ system, rehydrogenation seems to occur at more moderate conditions for the $\mathrm{Li}\left(\mathrm{BH}_{4}\right)_{1-\mathrm{x}} \mathrm{I}_{\mathrm{x}}$ solid solution as compared to $\mathrm{LiBH}_{4}{ }^{15} \mathrm{Ball}^{-}$ milling of $\mathrm{NaBH}_{4}$ and $\mathrm{NaCl}$, which are isostructural with a NaCl-type structure, results in the formation of a stable $\mathrm{Na}\left(\mathrm{BH}_{4}\right)_{1-\mathrm{x}} \mathrm{Cl}_{\mathrm{x}}$ solid solution. ${ }^{17,18}$ DSC measurements show that the stability increases with increasing the degree of chloride substitution. ${ }^{17}$ First-principles calculations predict that the decrease in the decomposition temperature introduced by $\mathrm{CaX} 2(\mathrm{X}=\mathrm{F}, \mathrm{Cl})$ in $\mathrm{Ca}\left(\mathrm{BH}_{4}\right)_{2}$ would be less than $10^{\circ} \mathrm{C} .{ }^{19}$ Iodide substitution in $\mathrm{Ca}\left(\mathrm{BH}_{4}\right)_{2}$ has been investigated, and three new mixed phases have been reported. DSC results show that hydrogen desorption for the substituted sample occurs at $5-10{ }^{\circ} \mathrm{C}$ higher than for the pure $\alpha-\mathrm{Ca}\left(\mathrm{BH}_{4}\right)_{2}{ }^{20}$

$\mathrm{Mg}\left(\mathrm{BH}_{4}\right)_{2}$ undergoes a polymorphic phase transition from $\alpha$ - to the $\beta$-polymorph at around $190{ }^{\circ} \mathrm{C}$ and then desorbs hydrogen at around $300{ }^{\circ} \mathrm{C} .{ }^{7,21}$ The $\beta$-polymorph is preserved in metastable condition upon cooling to room temperature (RT) without any conversion back to the $\alpha$-polymorph. A third, highly porous polymorph, $\gamma-\mathrm{Mg}\left(\mathrm{BH}_{4}\right)_{2}$, has also recently been reported. ${ }^{22}$ In the present study, partial substitution of $\mathrm{BH}_{4}$ by halide anion $\left(\mathrm{X}=\mathrm{Cl}, \mathrm{Br}\right.$ ) forming mixed phase $\mathrm{Mg}\left(\mathrm{BH}_{4}\right)_{2-\mathrm{X}} \mathrm{X}_{\mathrm{x}}$, has been attempted to change the hydrogen storage properties of $\mathrm{Mg}\left(\mathrm{BH}_{4}\right)_{2}$.

Moreover, ab initio calculations were run on the $\alpha$-phase of the pure borohydride to simulate $\mathrm{Cl}$ substitution inside the lattice. The choice of this phase was dictated by the feasibility of the periodic $a b$ initio calculations, which are quite demanding for large unit cells such as $\beta-\mathrm{Mg}\left(\mathrm{BH}_{4}\right)_{2}$ (twice as large as the $\alpha$-polymorph). Computed data are useful to indicate whether the halide substitution is favorable or not in both $\alpha$ - and $\beta$-polymorphs of $\mathrm{Mg}\left(\mathrm{BH}_{4}\right)_{2}$.

\section{EXPERIMENTAL SECTION}

Mixtures of $\mathrm{Mg}\left(\mathrm{BH}_{4}\right)_{2}$ and $\mathrm{MgX} 2(\mathrm{X}=\mathrm{Cl}, \mathrm{Br})$ in a molar 1:1 ratio were prepared by ball-milling (Pulverisette 7, Fritsch) using different milling speeds (280, 360, and $505 \mathrm{rpm}) \cdot \mathrm{Mg}\left(\mathrm{BH}_{4}\right)_{2}$ was synthesized by wet chemistry methods and $\mathrm{MgX}$ were purchased $\left(\mathrm{MgCl}_{2}: 98 \%\right.$, Merck; $\mathrm{MgBr}_{2}: 98 \%$, Aldrich). The samples were prepared in $0.5 \mathrm{~g}$ batches with 1:30 sample-to-ball mass ratio. Ball-milling was performed under $0.1 \mathrm{MPa}$ Ar atmosphere for $1 \mathrm{~h}$, followed by a $30 \mathrm{~min}$ pause, and repeated until reaching a total milling time of $12 \mathrm{~h}$. Sample handling was carried out in a MBraun Unilab glovebox filled with purified argon $\left(<1 \mathrm{ppm} \mathrm{O}_{2}\right.$ and $\left.\mathrm{H}_{2} \mathrm{O}\right)$ to avoid oxidation.

Powder X-ray diffraction (PXD) patterns were collected in transmission mode using $\mathrm{Cu}_{\alpha}$ radiation in a Bruker AXS D8 Advance diffractometer equipped with a Göbel mirror and a LynxEye 1D strip detector. The samples were contained in rotating boron glass capillaries $(0.8 \mathrm{~mm} \phi)$ filled and sealed under $\mathrm{Ar}$ atmosphere.

In situ synchrotron radiation (SR) PXD measurements $(\lambda=0.70947 \AA)$ were carried out using a MAR345 imaging plate detector at the Swiss-Norwegian Beamline (SNBL, BM01A) at the European Synchrotron Radiation Facility (ESRF), Grenoble, France. The samples were mounted in boron glass capillaries $(0.8$ $\mathrm{mm} \phi$ ) fixed in a Swagelok fitting and kept under $1 \mathrm{MPa}_{2}$. A diffraction pattern was collected every 2 min (exposure time of 30 and $90 \mathrm{~s}$ for data read-out). The capillary was rotated $30^{\circ}$ during exposure to improve the powder averaging. Measurements were carried out between $\mathrm{RT}$ and $300{ }^{\circ} \mathrm{C}$ with a ramp rate of $2{ }^{\circ} \mathrm{C} \mathrm{min}{ }^{-1}$ using a hot air blower. The two-dimensional data were integrated to one-dimensional diffraction patterns using the Fit2D program. ${ }^{23}$

High-resolution SR-PXD data $(\lambda=0.50123 \AA)$ were collected at the SNBL, BM01B at ESRF, Grenoble, France. The instrument is equipped with six scintillation detectors mounted with $1.1^{\circ}$ separation in $2 \theta$, each with a secondary monochromator. The samples were filled and sealed in boron glass capillaries $(0.5$ $\mathrm{mm} \phi$ ) with pure Si powder as internal standard under Ar atmosphere and placed on a spinning stage. The data were combined with a $0.003^{\circ}$ binning step size and analyzed by the Rietveld method using the GSAS software package ${ }^{24}$ with the EXPGUI ${ }^{25}$ user interface.

Differential scanning calorimetry (DSC) was carried out using a Setaram Sensys DSC with stainless steel pressure tight cell. The samples were heated from RT to $500{ }^{\circ} \mathrm{C}$ with a ramp rate of $2{ }^{\circ} \mathrm{C} \mathrm{min}{ }^{-1}$ under 1 $\mathrm{MPa} \mathrm{H}_{2}$.

Infrared spectra were recorded on the single-reflection ALPHA-Platinum ATR (attenuated total reflection) instrument (Bruker) with diamond crystal accessory. The instrument was contained in a glovebox with high-purity nitrogen. The spectra were obtained in a $4000-400 \mathrm{~cm}^{-1}$ range at $2 \mathrm{~cm}^{-1}$ resolution, 64 scans were averaged for each spectrum and the background was subtracted. Raman spectra were obtained with inVia Raman microscope, with $514 \mathrm{~nm}$ laser excitation line and a 20x 
UltraLongWorking Distance MSPlan Olympus objective. The spectra were recorded in the 3000-150 $\mathrm{cm}^{-1}$ range, with 10 acquisitions of $40 \mathrm{~s}$ per spectrum. Samples for Raman measurements were closed in quartz cells in a nitrogen atmosphere.

Computational Details. All the calculations presented in this study were performed by applying the periodic quantum-mechanical software CRYSTAL09. ${ }^{26}$ Because of the large size of the $\alpha-\mathrm{Mg}\left(\mathrm{BH}_{4}\right)_{2}$ unit cell (more than 300 atoms), the following strategy was adopted to reduce the computational costs: (i) Hartree-Fock (HF) calculations were run to optimize only cell parameters of both pure and mixed structures; ${ }^{27}$ (ii) on the HF optimized geometries, calculations with the GGA PBE functional (Perdew-Burke-Ernzerhof parametrization of the generalized gradient approximation) were conducted; ${ }^{28}$ (iii) the hybrid B3LYP functional was also considered for single point calculations on the PBE-optimized structures for comparison. $^{29}$

The CRYSTAL code utilizes localized Gaussian functions to describe electrons, and in step i, a minimum basis set of Slater-Type-Orbitals simulated by three Gaussian functions (STO-3G) was used, ${ }^{30}$ while in steps ii and iii, polarized double- $\zeta$ functions were utilized. Specifically, a 8-511d1G was adopted for $\mathrm{Mg},{ }^{31}$ and $\mathrm{B}$ was described by a 6-21G(d) basis set; ${ }^{32}$ for $\mathrm{H}$ a $31 \mathrm{G}(\mathrm{p})^{33}$ was applied, and for $\mathrm{Cl}$ a $86-311 \mathrm{G}$ with an additional d orbital $\left(\alpha_{d}=0.750\right.$ bohr $\left.^{-2}\right)$ was applied. ${ }^{34}$

\section{RESULTS AND DISCUSSION}

The milled mixtures were routinely investigated by laboratory PXD after milling, and selected results are shown in Figure 1. The diffraction data of the samples milled with $\mathrm{MgCl}_{2}$ and $\mathrm{MgBr}_{2}$ at 280 (Figure $1 \mathrm{a}$ and 1c) and $360 \mathrm{rpm}$ (not shown) revealed mechanical mixtures of $\alpha-\mathrm{Mg}\left(\mathrm{BH}_{4}\right)_{2}$ and the halide with no sign of a chemical reaction. For the sample milled at the highest speed (505 rpm), $\mathrm{Mg}\left(\mathrm{BH}_{4}\right)_{2}$ turned nanocrystalline or amorphous as shown in Figure $1 \mathrm{~b}$ and 1d.

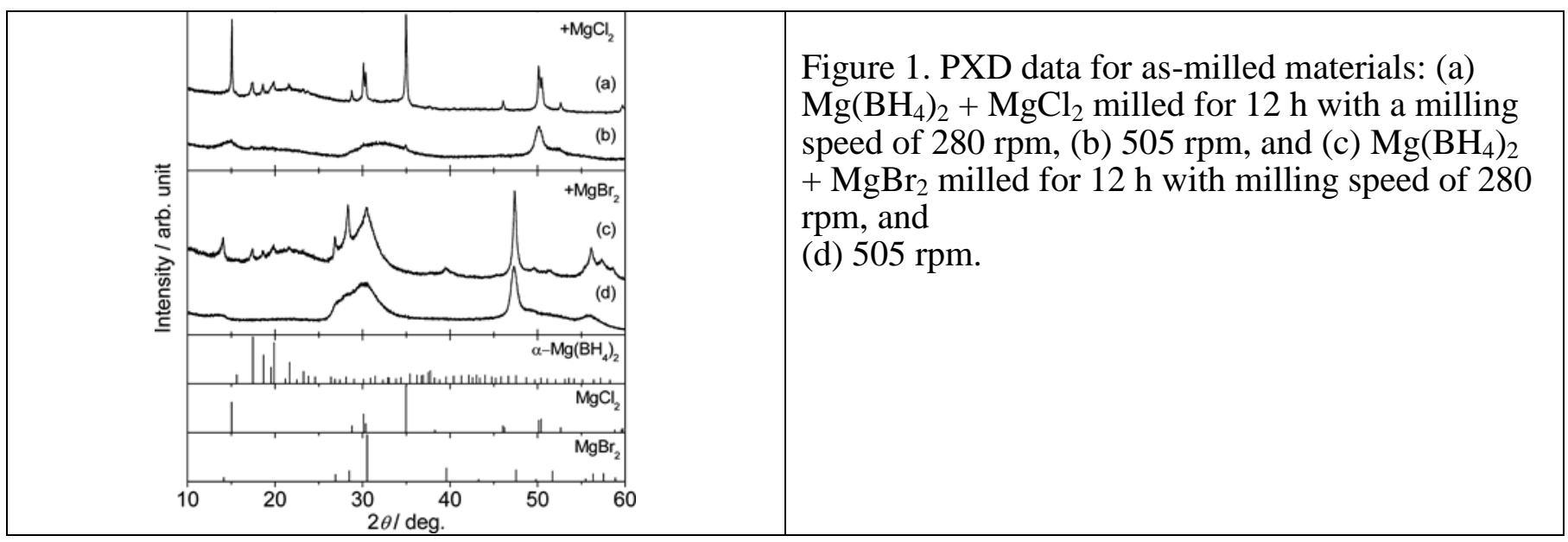

Figure 2 shows in situ SR-PXD patterns of $\mathrm{Mg}\left(\mathrm{BH}_{4}\right)_{2}+\mathrm{MgCl}_{2}$ milled at $505 \mathrm{rpm}$ during heating from RT to $300{ }^{\circ} \mathrm{C}$

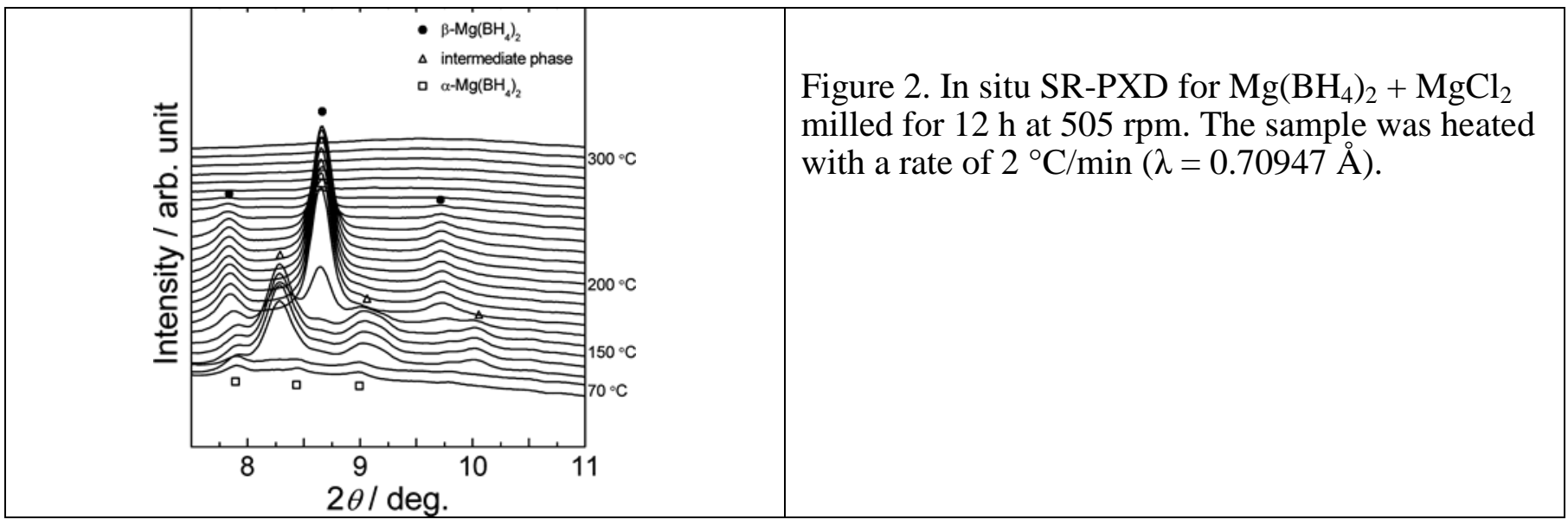


with a rate of $2{ }^{\circ} \mathrm{C} \min ^{-1}$. In the beginning, small peaks from $\alpha-\operatorname{Mg}\left(\mathrm{BH}_{4}\right)_{2}$, which were too weak to be seen by lab-PXD, were observed, indicating that the milled sample is nanocrystalline rather than amorphous. $\alpha-\mathrm{Mg}\left(\mathrm{BH}_{4}\right)_{2}$ was transformed to an unknown intermediate phase at $123{ }^{\circ} \mathrm{C}$ and then to $\beta$ $\mathrm{Mg}\left(\mathrm{BH}_{4}\right)_{2}$ at $162^{\circ} \mathrm{C}$. The $\beta$-phase disappeared at $274{ }^{\circ} \mathrm{C}$. The same intermediate phase is observed under the same conditions for the samples of $\mathrm{Mg}\left(\mathrm{BH}_{4}\right)_{2}+\mathrm{MgCl}_{2}$ milled at $360 \mathrm{rpm}$ and $\mathrm{Mg}\left(\mathrm{BH}_{4}\right)_{2}+\mathrm{MgBr}_{2}$ milled at $505 \mathrm{rpm}$, respectively. This unknown intermediate phase has a similar PXD fingerprint as a product obtained from heating commercial $\gamma-\mathrm{Mg}\left(\mathrm{BH}_{4}\right)_{2}$ (Aldrich). It was found that the $\gamma$-polymorph transforms to an intermediate phase (tentatively named $\left.\varepsilon-\mathrm{Mg}\left(\mathrm{BH}_{4}\right)_{2}\right)$ after heating to $170{ }^{\circ} \mathrm{C} . \varepsilon-\mathrm{Mg}\left(\mathrm{BH}_{4}\right)_{2}$ then transforms to the $\beta$-polymorph after heating up to $210^{\circ} \mathrm{C}$ (shown in Supporting Information Figure $\mathrm{S} 1$ ). There are not enough observed peaks of the unknown phase in the PXD data for the halidecontaining sample to make a certain phase identification.

However, it seems likely that the unidentified phase is the $\varepsilon$-polymorph of $\operatorname{Mg}\left(\mathrm{BH}_{4}\right)_{2}$. This polymorph has not previously been observed to form from $\alpha-\mathrm{Mg}\left(\mathrm{BH}_{4}\right)_{2}$, and therefore it appears that substitution or ballmilling could alter the relative stability of the different $\mathrm{Mg}\left(\mathrm{BH}_{4}\right)_{2}$ polymorphs.

The samples milled at $280 \mathrm{rpm}$ were then annealed at a temperature close to the $\alpha \rightarrow \beta$ transition temperature, i.e. at $200{ }^{\circ} \mathrm{C}$, for $10 \mathrm{~h}$ under $1 \mathrm{MPa} \mathrm{H}$ back-pressure. Subsequent PXD measurements (lab and/or synchrotron) always showed a complete conversion to $\beta-\mathrm{Mg}\left(\mathrm{BH}_{4}\right)_{2}$ which did not reverse to the $\alpha$ polymorph on cooling to RT. There were clear shifts in the positions of Bragg peaks belonging to $\beta$ $\mathrm{Mg}\left(\mathrm{BH}_{4}\right)_{2}$ in both the Cl- and Br-containing samples after annealing, as compared to pure $\beta-\mathrm{Mg}\left(\mathrm{BH}_{4}\right)_{2}$, as shown in Figure 3. Because $\alpha-$

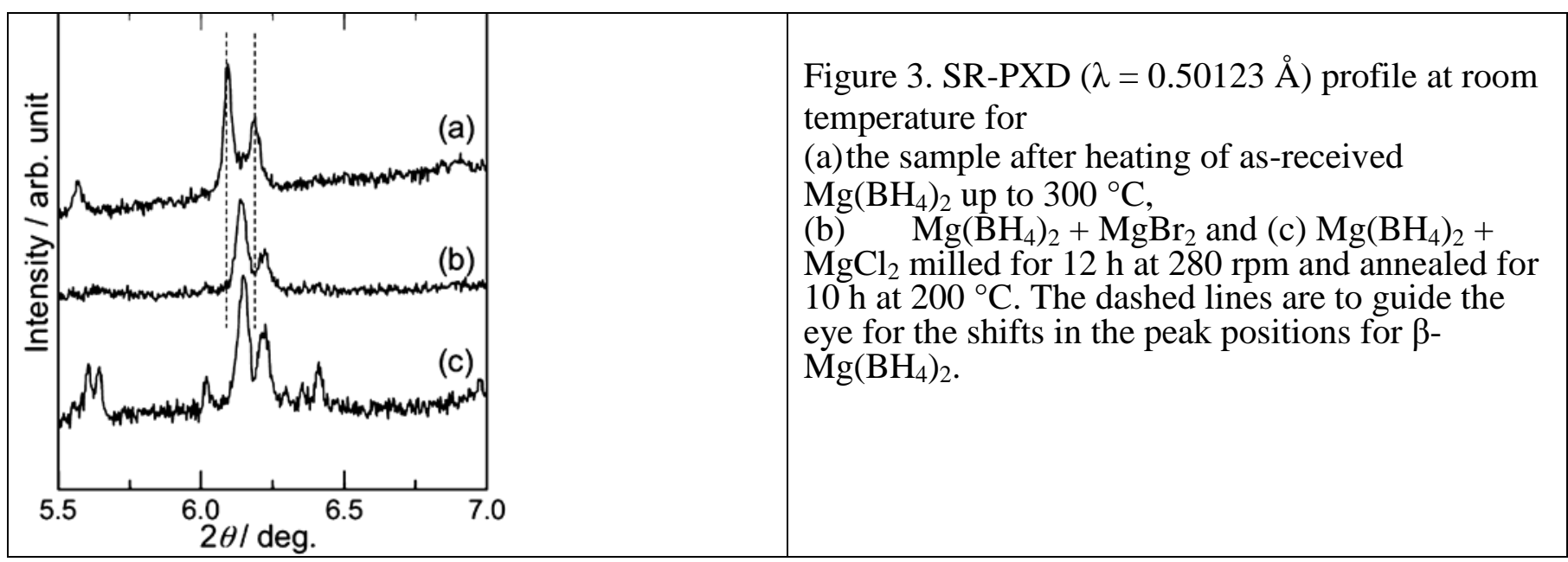

$\mathrm{Mg}\left(\mathrm{BH}_{4}\right)_{2}$ (without halide) milled and annealed under the same conditions does not show a similar peak shift (shown in Supporting Information Figure S2), it is clear that the shifts are due to substitution of $\mathrm{BH}_{4}{ }^{-}$ (ionic radius $r=2.05 \AA)$ by $\mathrm{Cl}^{-}(\mathrm{r}=1.81 \AA)$ or $\mathrm{Br}^{-}(\mathrm{r}=1.96 \AA)$. Structure refinement revealed that unit cell parameters decreased by about $0.1-0.2 \AA$ for $\beta-\mathrm{Mg}\left(\mathrm{BH}_{4}\right)_{2}$ in the mixtures, which corresponds to a volume contraction of the unit cell of about $2 \%$ (Table 1). For samples

Table 1. Unit Cell Parameters of $\beta-\mathrm{Mg}\left(\mathrm{BH}_{4}\right)_{2}$ in the Milled and Annealed Samples

\begin{tabular}{llll} 
sample & a, $\AA$ & b, $\AA$ & c, $\AA$ \\
\hline $\mathrm{Mg}\left(\mathrm{BH}_{4}\right)_{2}$ heated to $300{ }^{\circ} \mathrm{C}$ & 37.103 & 18.633 & 10.905 \\
$\mathrm{Mg}\left(\mathrm{BH}_{4}\right)_{2}+\mathrm{MgBr}_{2}$ milled for $12 \mathrm{~h}(280$ & 36.878 & 18.519 & 10.815 \\
$\mathrm{rpm})$ and annealed at $200 \quad{ }^{\circ} \mathrm{C}$ for $10 \mathrm{~h}$ & & & \\
$\mathrm{Mg}\left(\mathrm{BH}_{4}\right)_{2}+\mathrm{MgCl}_{2}$ milled for $12 \mathrm{~h}(280$ & 36.891 & 18.510 & 10.803 \\
rpm) and annealed at $200 \quad{ }^{\circ} \mathrm{C}$ for $10 \mathrm{~h}$ & & &
\end{tabular}

milled at higher speeds, the Bragg peaks were broad even after annealing, and therefore such subtle peak shifts were not possible to reveal. Estimations of quantities of substituted ions from intensities of diffraction peaks were difficult because of peak broadening. 
Figure 4 shows DSC profiles of pure $\alpha-\mathrm{Mg}\left(\mathrm{BH}_{4}\right)_{2}$ and of the mixtures of $\alpha-\mathrm{Mg}\left(\mathrm{BH}_{4}\right)_{2}$ and $\mathrm{MgCl}_{2}$ milled at 280 and $505 \mathrm{rpm}$

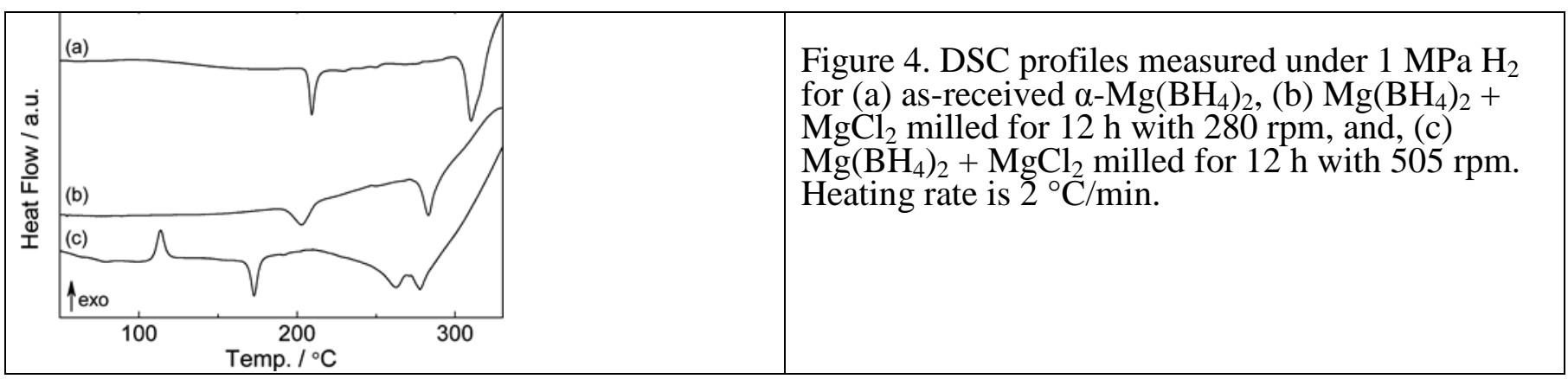

measured under $1 \mathrm{MPa}$ hydrogen back pressure. $\alpha-\mathrm{Mg}\left(\mathrm{BH}_{4}\right)_{2}$ shows two endothermic events at $210{ }^{\circ} \mathrm{C}$ and $310^{\circ} \mathrm{C}$ which are attributed to the transformation from $\alpha$ - to $\beta$-polymorphs and $\mathrm{H}_{2}$ desorption, respectively. The temperature of $\mathrm{H}_{2}$ desorption for the mixture milled at $280 \mathrm{rpm}$ is decreased by $30{ }^{\circ} \mathrm{C}$ compared to pure $\mathrm{Mg}\left(\mathrm{BH}_{4}\right)_{2}$. The sample milled at $505 \mathrm{rpm}$ shows an additional exothermic peak at around $120{ }^{\circ} \mathrm{C}$, which could be due to crystallization of the intermediate $\varepsilon$-phase from the nanocrystalline $\alpha-\mathrm{Mg}\left(\mathrm{BH}_{4}\right)_{2}$. The endothermic peak at around $170{ }^{\circ} \mathrm{C}$ should correspond to transformation from $\varepsilon$ - to $\beta$ polymorphs, and the hydrogen desorption corresponds to the broad endotherm with two peak at around $260{ }^{\circ} \mathrm{C}$ and $270{ }^{\circ} \mathrm{C}$. The $\alpha-\mathrm{Mg}\left(\mathrm{BH}_{4}\right)_{2}-\mathrm{MgBr}_{2}$ mixtures showed DSC profiles similar to those of the $\mathrm{MgCl}_{2}$ mixtures (shown in the Supporting Information Figure S3).

IR and Raman spectroscopy were used to investigate changes in $\mathrm{B}-\mathrm{H}$ bond energy for $\mathrm{BH}_{4}{ }^{-}$ion by the partial substitution. Figure 5 shows IR spectra of the $\mathrm{Mg}\left(\mathrm{BH}_{4}\right)_{2}-\mathrm{MgCl}_{2}$ mixtures ball-milled at 360 and $505 \mathrm{rpm}$ both as-milled and after annealing at $200{ }^{\circ} \mathrm{C}$. The absorption bands corresponding to the stretching and bending vibration of $\mathrm{B}-\mathrm{H}$ were observed in

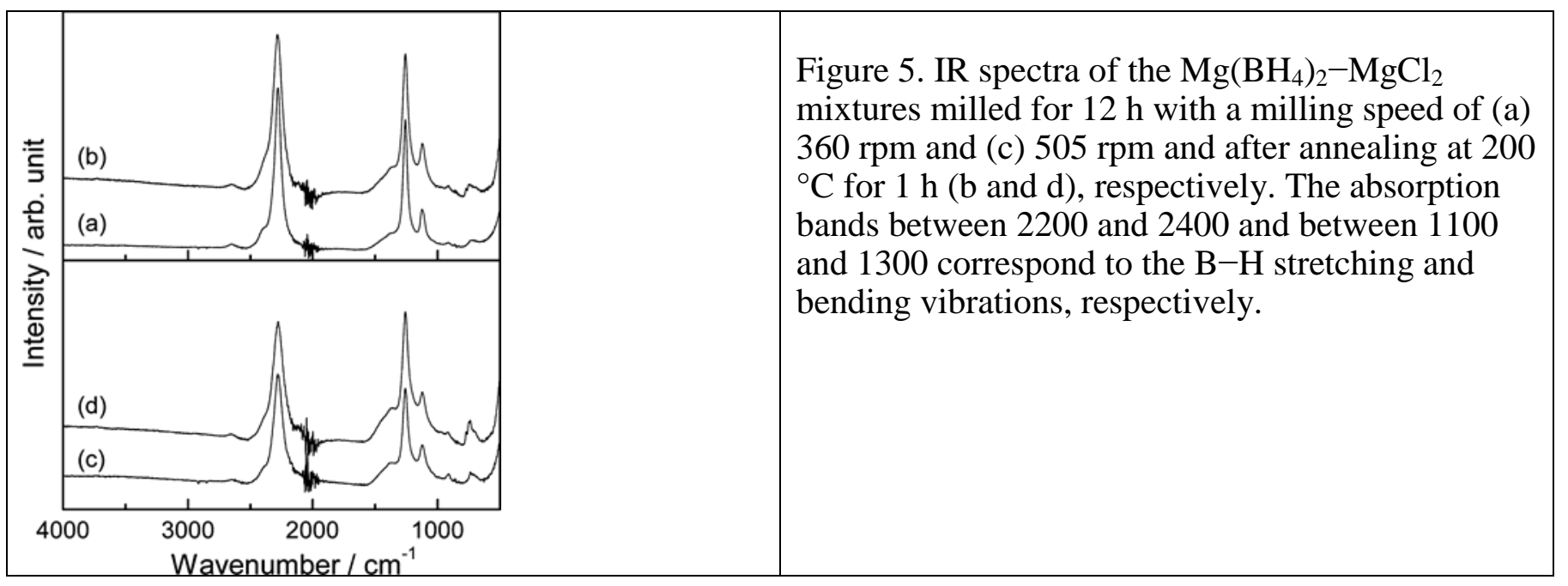

the regions between 2200 and $2400 \mathrm{~cm}^{-1}$ and 1100 and $1300 \mathrm{~cm}^{-1}$, respectively. The peaks of these vibration modes are at the same position for all the as-milled and as-annealed samples and are also similar to those observed for pure $\alpha$ - and $\beta-\mathrm{Mg}\left(\mathrm{BH}_{4}\right)_{2}$. Borohydrides are often hampered by water contamination, which may cause unfavorable side reactions. It can be observed that there are no absorption bands corresponding to molecular water $\left(\mathrm{O}-\mathrm{H}\right.$ stretching at ca. $3500 \mathrm{~cm}^{-1}$ and the $\mathrm{H}-\mathrm{O}-\mathrm{H}$ bending at ca. 1650 $\mathrm{cm}^{-1}$ ). However, a very weak peak due to isolated $\mathrm{OH}$ groups can be observed at ca. $3700 \mathrm{~cm}^{-1}$.

Furthermore, several peaks are observed at ca. 1400, 920, and $750 \mathrm{~cm}^{-1}$, which are not present in the spectrum of any of the pure $\mathrm{Mg}\left(\mathrm{BH}_{4}\right)_{2}$ polymorphs. These could correspond to the $\mathrm{B}-\mathrm{O}$ stretching and bending. On the other hand, they could also result from the combination modes of $\mathrm{BH}_{4}{ }^{-}$vibrations and libration. This indicates that the $\mathrm{BH}_{4}^{-} \rightarrow \mathrm{Cl}^{-}$substitution does not have much influence on the IR signal. The Raman spectra of the ball-milled samples are very fluorescent, and only the weak peaks due to B-H 
bending and stretching can be observed (shown in the Supporting Information Figure S4). The Raman spectra of the annealed mixtures are even more fluorescent and are not shown.

Periodic ab initio calculations were performed on the initial

$\alpha$ "structure data of $-\mathrm{Mg}\left(\mathrm{BH}_{4}\right)_{2}$ reported by Filinchuk, Cerny,

and Hagemann. ${ }^{35}$ This phase was chosen because it represents the stable phase at RT, and it has half the number of atoms in the unit cell compared to $\beta-\mathrm{Mg}\left(\mathrm{BH}_{4}\right)_{2}$, meaning that it is less computationally demanding. Still, the $\alpha$-phase (hexagonal,

$\mathrm{P}_{1} 22$ space group) contains 330 atoms $\left(\mathrm{Mg}_{30} \mathrm{~B}_{60} \mathrm{H}_{240}\right)$ in the unit cell, as displayed in Figure 6 . The optimized unit cell

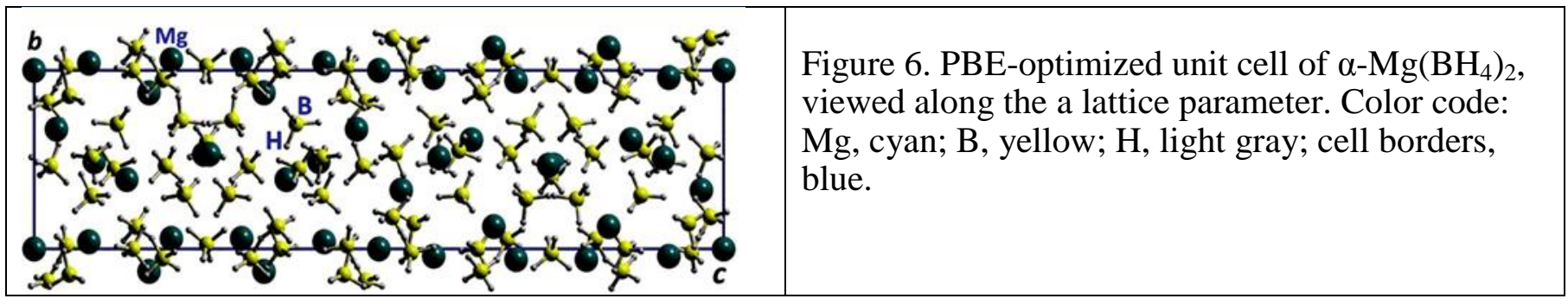

parameters turned out to be $\mathrm{a}=\mathrm{b}=10.37 \AA, \mathrm{c}=36.81 \AA$ and $\alpha$ $=\beta=90^{\circ}, \gamma=120^{\circ}$. The completely chlorinated structure, $\mathrm{MgCl}_{2}$ (not shown), was simulated starting from the lattice constants of the borohydride. As expected, the optimized unit cell parameters $(\mathrm{a}=\mathrm{b}=$ $10.36 \AA, c=36.03 \AA$ and $\alpha=\beta=90^{\circ}, \gamma$

$=120^{\circ}$ ) are slightly reduced with respect to the borohydride, because of the slightly smaller ionic radius of $\mathrm{Cl}^{-}$compared to the $\mathrm{BH}_{4}^{-}$unit.

A complex task was to determine which configurations to compute for the halide-substituted $\alpha$-phase with a given molar composition $\mathrm{x}$, with $\mathrm{x}$ ranging from $0\left(\mathrm{Mg}\left(\mathrm{BH}_{4}\right)_{2}\right)$ to $1\left(\mathrm{MgCl}_{2}\right)$. Symmetry criteria were followed, since only 6 irreducible $\mathrm{B}$ atoms are present in the unit cell, out of the total 60 . Considering these symmetry relations, structures with varying content of $\mathrm{Cl}$ have been computed, starting from $10 \%$ to the $80 \%$ of the total number of borohydride tetrahedra in the unit cell $(0.1<\mathrm{x}<0.8)$. By analyzing the optimized geometries, a reduction of about $2 \%$ for both a and c parameters was

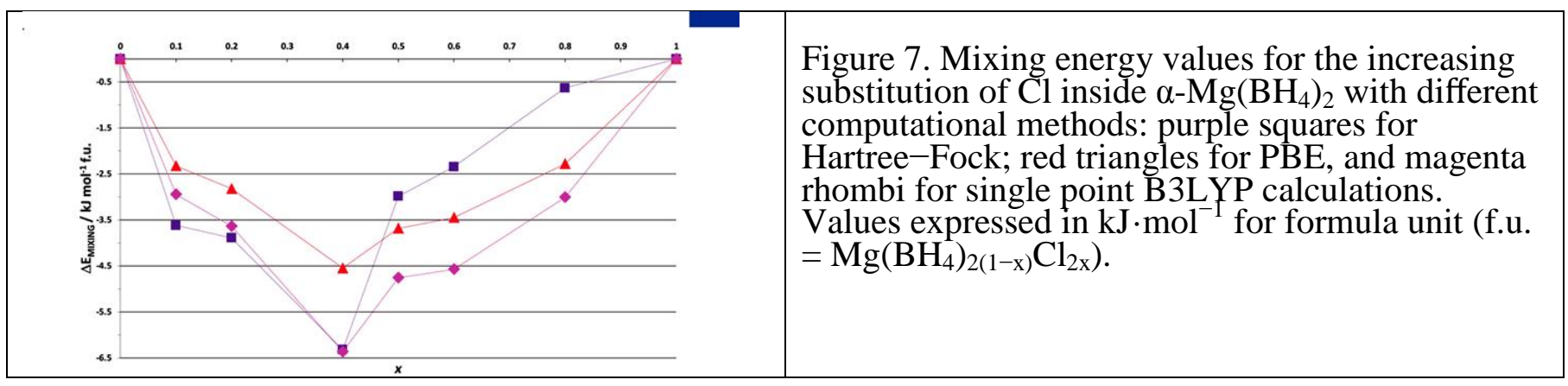

observed, in line with the experimental findings for the $\beta$ phase (see Table 1).

From the electronic energy values of the optimized structures, the mixing $E$ for the following reaction was computed

$(1-x) \alpha-\mathrm{Mg}\left(\mathrm{BH}_{4}\right)_{2}+x \mathrm{MgCl}_{2} \rightarrow \mathrm{Mg}\left(\mathrm{BH}_{4}\right)_{2(1-x)} \mathrm{Cl}_{2 x}$

where all species have the same structure type of $\alpha-\mathrm{Mg}\left(\mathrm{BH}_{4}\right)_{2}$. To take the temperature into account when thermodynamic properties are computed, the electronic energy has to be corrected for the zero point energy (ZPE) and for a thermal factor. Nevertheless, in this case, frequency calculations were not feasible because of the excessive computational cost, so the electronic energy has been used as a reference for the enthalpy of the reaction. As already mentioned in the computational details, different approaches were applied due to the large size of the cell (HF, PBE, and B3LYP methods). Figure 7 shows the electronic 
energy values, obtained with the three methods, as a function of $\mathrm{Cl}$ content, i.e., for increasing $\mathrm{x}$ values. The results suggest that the mixing reaction appears to be promoted, because all methods give negative values of E. As expected, the HF technique overestimates the energies, while the B3LYP underestimates them, with respect to the standard PBE functional.

The conditions for formation of a solid solution in the $\mathrm{Mg}\left(\mathrm{BH}_{4}\right)_{2}-\mathrm{MgCl}_{2}$ system can be described in terms of thermodynamic arguments. In fact, in the case of the $\alpha$-phase, it has been shown that a negative energy of mixing, close to $-5 \mathrm{~kJ} \cdot \mathrm{mol}^{-1}$, can promote the formation of the solid

solution. Considering negligible ZPE (i.e., taking mixing $E$ as an estimated of the enthalpy of mixing) and taking an ideal

entropy of mixing, a schematic picture of the free energy- composition curves at RT is shown in Figure 8, where curve a represents a possible trend for the $\alpha$-solid solution. For $\alpha-\mathrm{Mg}\left(\mathrm{BH}_{4}\right)_{2}$, it starts from 0 , because the $\alpha$-phase is stable at RT. On the contrary, $\mathrm{MgCl}_{2}$ has at RT a trigonal structure (R-3m space group). So, the curve of the free energy of the solid solution has been schematically drawn up to the position of

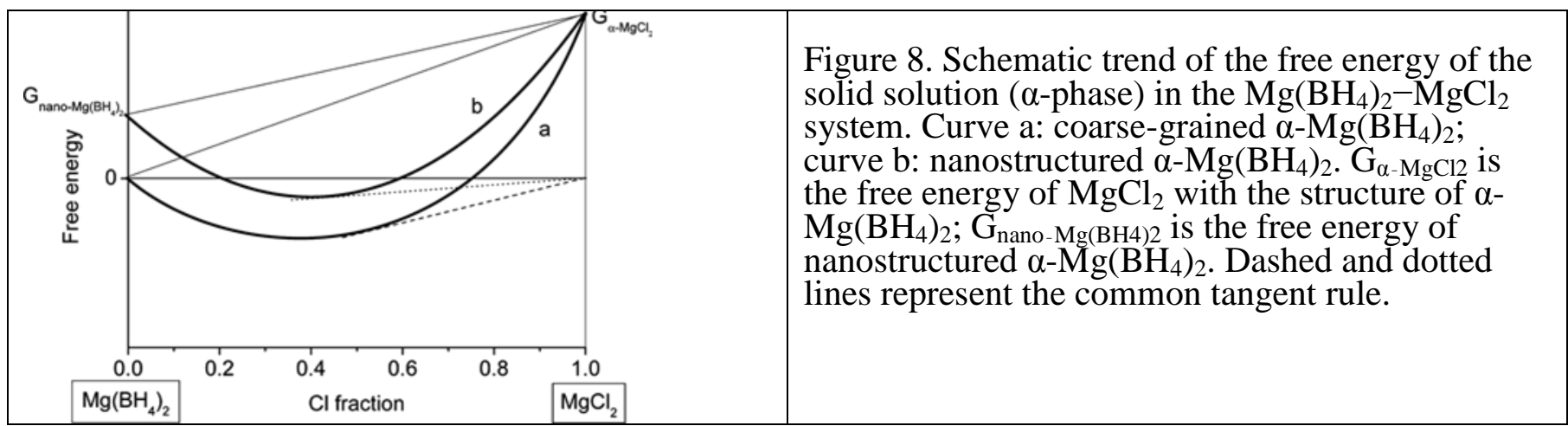

$\mathrm{MgCl}_{2}$ with the structure of $\alpha-\mathrm{Mg}\left(\mathrm{BH}_{4}\right)_{2}\left(\mathrm{G}_{\alpha-\mathrm{MgCl} 2}\right.$ in Figure 8). Using the common tangent rule (dashed line in Figure 8), the limit of solubility can be envisaged. If $\alpha-\mathrm{Mg}\left(\mathrm{BH}_{4}\right)_{2}$ could dissolve in trigonal $\mathrm{MgCl}_{2}$, the free energy scenario would obviously be different. It is interesting to note that the occurrence of a nanostructuring in the parent $\alpha-\mathrm{Mg}\left(\mathrm{BH}_{4}\right)_{2}$ is hindering the formation of the solid solution. In fact, in this case the free energy curve would start from a positive value $\left(\mathrm{G}_{\text {nano-Mg(BH4)2 }}\right.$ in Figure 8$)$ because of the increase in free energy related to microstructural refinement (defects, grain boundaries, dislocations, etc.) in $\alpha-\mathrm{Mg}\left(\mathrm{BH}_{4}\right)_{2}$. In this case, the trend of the free energy would be different (curve $b$ ) and the common tangent rule (dotted line in Figure 8) would come to a lower maximal $\mathrm{Cl}^{-}$dissolution in $\left.\alpha-\mathrm{Mg}_{(\mathrm{BH}}\right)_{2}$. This scheme could explain the limited dissolution observed after ball-milling.

The explanation of the observed formation of a solid solution in the $\beta-\mathrm{Mg}\left(\mathrm{BH}_{4}\right)_{2}$ would need a picture of the enthalpy of mixing for this phase. As stated above, this value cannot be obtained from ab initio calculations because of the very large size of the unit cell. Moreover, experimental data on the enthalpy of mixing are not available. Combining the results of the experimental and theoretical works presented above, an estimation of the thermodynamics of the dissolution of $\mathrm{MgCl}_{2}$ in $\beta-\mathrm{Mg}\left(\mathrm{BH}_{4}\right)_{2}$ can be carried out. The temperature depend-ence of the free energy of formation of $\mathrm{Mg}\left(\mathrm{BH}_{4}\right)_{2}$ has been recently estimated for both the $\alpha$ - and $\beta$-polymorphs, on the basis of a combination of ab initio and Calphad calculations. ${ }^{36}$ The authors have considered a constant enthalpy and entropy of formation, so that the free energy turns out as a straight line as a function of temperature, as shown in Figure 9. The 


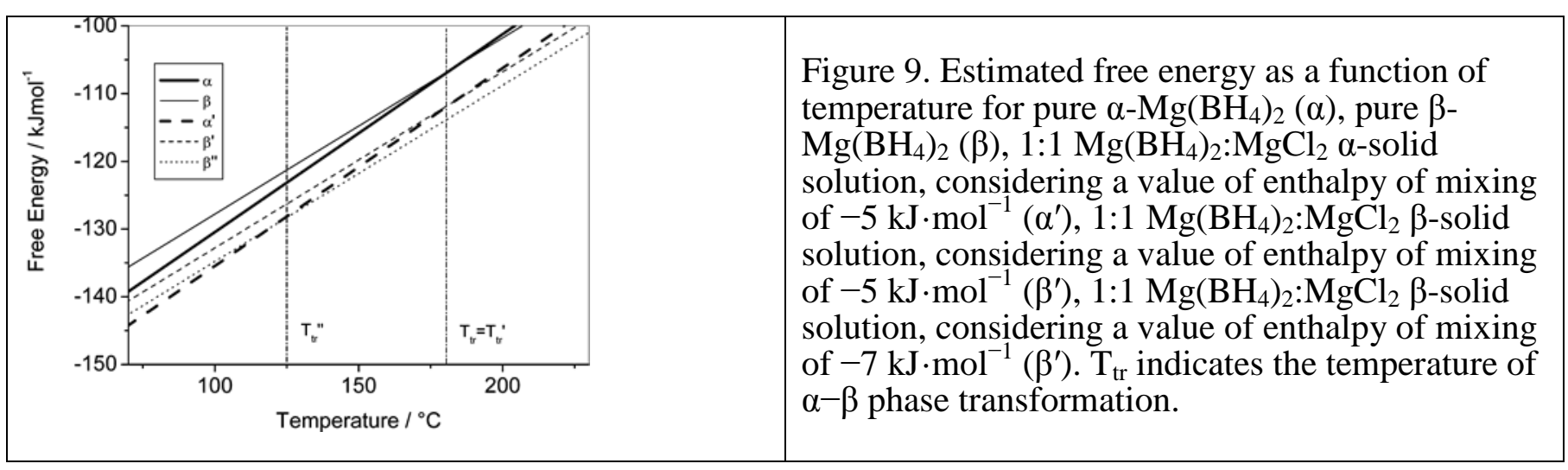

temperature of the $\alpha-\beta$ phase transformation $\left(\mathrm{T}_{\mathrm{tr}}\right)$ was fixed at $180{ }^{\circ} \mathrm{C}$. If we consider a $1: 1$ composition, the trend of the free energy of the $\alpha$-solid solution can be estimated when a value of enthalpy of mixing of $-5 \mathrm{~kJ} \cdot \mathrm{mol}^{-1}$ is considered, as shown in Figure 9. If the same value of enthalpy of mixing would be present in the $\beta$-solid solution, the temperature of $\alpha-\beta$ phase transformation for the solid solution $\left(\mathrm{T}_{\text {tr }}{ }^{\prime}\right)$ would not change with respect to that of pure $\alpha-\mathrm{Mg}\left(\mathrm{BH}_{4}\right)_{2}$, as shown in Figure 9. On the other hand, if the enthalpy of mixing for the $\beta$-solid solution were more negative with respect to that of the $\alpha$-solid solution, a decrease in the temperature of $\alpha-\beta$ phase transformation would be expected. This trend is described in Figure 9, where the free energy of the $\beta$-solid solution has been estimated considering an enthalpy of mixing of $-7 \mathrm{~kJ} \cdot \mathrm{mol}^{-1}$ for the same $1: 1$ composition. In this case, the temperature of $\alpha-\beta$ phase transformation $\left(\mathrm{T}_{\mathrm{tr}}{ }^{\prime \prime}\right)$ is lowered, exhibiting similar trends in DSC measurements (Figure 4). Therefore, also for the $\beta$-phase a negative enthalpy of mixing is expected, which drives the formation of a solid solution. In this case, because of the higher temperatures, the kinetics of solubility is promoted, explaining the results observed experimentally.

\section{CONCLUSIONS}

In this work, substitution of $\mathrm{BH}_{4}{ }^{-}$ion (ionic radius $\left.\mathrm{r}=2.05 \AA\right)$ by halide ion $\mathrm{Cl}^{-}(\mathrm{r}=1.81 \AA) / \mathrm{Br}^{-}(\mathrm{r}=$ $1.96 \AA$ ) is observed for the first time in $\beta-\mathrm{Mg}\left(\mathrm{BH}_{4}\right)_{2}$ after annealing a milled mixture of

$\alpha-\mathrm{Mg}\left(\mathrm{BH}_{4}\right)_{2}+\mathrm{MgX}_{2}(\mathrm{X}=\mathrm{Cl}, \mathrm{Br})$. The substitution is evident from the shift of Bragg peaks to higher angles. A slight reduction in temperature of hydrogen desorption due to the partial substitution is observed.

$\mathrm{Ab}$ initio calculations indicate that the reaction between the $\alpha$-phase of $\mathrm{Mg}\left(\mathrm{BH}_{4}\right)_{2}$ and $\mathrm{MgCl}_{2}$ is favored because the mixed structure are stabilized by the presence of $\mathrm{Cl}$ inside the lattice. These results are in agreement with the experimental ones measured for the $\beta$-phase. A combined experimental and theoretical approach for the $\mathrm{Cl}$ substitution in $\mathrm{Mg}\left(\mathrm{BH}_{4}\right)_{2}$ results in estimating a more negative enthalpy of mixing for the $\beta$-solid solution than for the $\alpha$-solid solution.

\section{ACKNOWLEDGMENTS}

This research was financially supported by the European Community's Seventh Framework Program FP7/2007-2013 under grant agreement no. 226943-FLYHY, a Marie Curie International Incoming Fellowship within the seventh Euro-pean Community Framework Programme (FP7-PEOPLE-2009-IIF, no. 253863), and by the RENERGI program of the Research Council of Norway. The authors acknowledge the skillful assistance from the staff of the Swiss-Norwegian Beamline, at the European Synchrotron Radiation Facility, Grenoble, France.

\section{REFERENCES}

(1) Orimo, S.; Nakamori, Y.; Eliseo, J. R.; Züttel, A.; Jensen, C. M.

Chem. Rev. 2007, 107, 4111-4132.

(2) Li, H.-W.; Yan, Y.; Orimo, S.; Züttel, A.; Jensen, C. M. Energies 2011, 4, 185-214. 
(3) Rude, L. H.; Nielsen, T. K.; Ravnsbaek, D. B.; Bosenberg, U.; Ley, M. B.; Richter, B.; Arnbjerg, L. M.; Dornheim, M.; Filinchuk, Y.; Besenbacher, F.; et al. Phys. Status Solidi A 2011, 208, 1754-1773.

(4) Rongeat, C.; D’Anna, V.; Hagemann, H.; Borgschulte, A.; Züttel, A.; Schultz, L.; Gutfleisch, O. J. Alloys Compd. 2010, 493, 281-287.

(5) Bardají, E. G.; Zhao-Karger, Z.; Boucharat, N.; Nale, A.; van Setten, M. J.; Lohstroh, W.; Röhm, E.; Catti, M.; Fichtner, M. J. Phys. Chem. C 2011, 115, 6095-6101.

(6) Nakamori, Y.; Miwa, K.; Ninomiya, A.; Li, H.-W.; Ohba, N.; Towata, S.; Züttel, A.; Orimo, S. Phys. Rev. B 2006, 74, 045126.

(7) Chlopek, K.; Frommen, C.; Leon, A.;Zabara, O.; Fichtner, M. J. Mater. Chem. 2007, 17, 3496-3503.

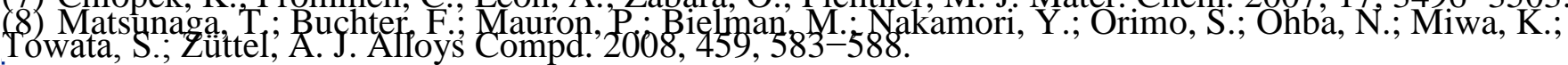

(9) Vajo, J. J.; Skeith, S. L.; Mertens, F. J. Phys. Chem. B 2005, 109, 3719-3722.

(10) Li, H.-W.; Orimo, S.; Nakamori, Y.; Miwa, K.; Ohba, N.; Towata, S.; Züttel, A. J. Alloys Compd. 2007, 446-447, 315-318.

(11) Au, M.; Jurgensen, A. J. Phys. Chem. B 2006, 110, 7062-7067.

(12) Gross, A. F.; Vajo, J. J.; VanAtta, S. L.; Olson, G. L. J. Phys. Chem. C 2008, 112, 5651-5657.

(13) Sartori, S.; Knudsen, K. D.; Zhao-Karger, Z.; Bardaji, E. G.; Muller, J.; Fichtner, M.; Hauback, B. C. J. Phys. Chem. C 2010, 114, 18785-18789.

(14) Brinks, H. W.; Fossdal, A.; Hauback, B. C. J. Phys. Chem. C 2008, 112, 5658-5661.

(15) Rude, L. H.; Groppo, E.; Arnbjerg, L. M.; Ravnsbæk, D. B.; Malmkjær, R. A.; Filinchuk, Y.;

Baricco, M.; Besenbacher, F.; Jensen, T. R. J. Alloys Compd. 2011, 509, 8299-8305.

(16) Rude, L. H.; Zavorotynska, O.; Arnbjerg, L. M.; Ravnsbæk, D. B.; Malmkjær, R. A.; Grove, H.; Hauback, B. C.; Baricco, M.; Filinchuk, Y.; Besenbacher, F.; et al. Int. J. Hydrogen Energy 2011, 36, 15664-15672.

(17) Olsen, J. E.; Sørby, M. H.; Hauback, B. C. J. Alloys Compd. 2011, 509, L228-L231.

(18) Ravnsbæk, D. B.; Rude, L. H.; Jensen, T. R. J. Solid State Chem. 2011, 184, 1858-1866.

(19) Lee, J. Y.; Lee, Y.-S.; Suh, J.-Y.; Shim, J.-H.; Cho, Y. W. J. Alloys Compd. 2010, 506, 721-727.

(20) Rude, L. H.; Filinchuk, Y.; Sørby, M. H.; Hauback, B. C.; Besenbacher, F.; Jensen, T. R. J. Phys. Chem. C 2011, 115, 7768-7777.

(21) Riktor, M. D.; Sorby, M. H.; Chlopek, K.; Fichtner, M.; Buchter, F.; Zuettel, A.; Hauback, B. C. J. Mater. Chem. 2007, 17, 4939-4942.

(22) Filinchuk, Y.; Richter, B.; Jensen, T. R.; Dmitriev, V.; Chernyshov, D.; Hagemann, H. Angew. Chem., Int. Ed. 2011, 50, 11162-11166.

(23) Hammersley, A. P. FIT2D: An Introduction and Overview; ESRF Internal Report, ESRF: Grenoble, France, 1997.

(24) Larson, A. C.; Von Dreele, R. B. General Structure Analysis System (GSAS); Los Alamos National Laboratory Report LAUR 86-748, Los Alamos National Laboratory: Los Alamos, NM, 1994.

(25) Toby, B. H. J. Appl. Crystallogr. 2001, 34, 210-213.

(26) Dovesi, R.; Saunders, V. R.; Roetti, C.; Orlando, R.; Zicovich-Wilson, C. M.; Pascale, F.; Civalleri, B.; Doll, K.; Harrison, N. M.; Bush, I. J.; D’Arco, P.; et al. CRYSTAL2009 User's Manual; University of Torino: Torino; 2009.

(27) Pisani, C.; Dovesi, R. Int. J. Quantum Chem. 1980, 17, 501-516.

(28) Perdew, J. P.; Burke, K.; Ernzerhof, M. Phys. Rev. Lett. 1996, 77, 3865-3868.

(29) Becke, A. D. J. Chem. Phys. 1993, 98, 5648-5652.

(30) Hehre, W. J.; Stewart, R. F.; Pople, J. A. J. Chem. Phys. 1969, 51, 2657-2664.

(31) Valenzano, L.; Noel;"Y.; Orlando, R.; Zicovich-Wilson, C.; Ferrero, M.; Dovesi, R. Theor. Chem.

Acc. 2007, 117, 991-1000.

(32) Orlando, R.; Dovesi, R.; Roetti, C.; Saunders, V. R. J. Phys.: Condens. Matter 1990, 2, 7769-7789.

(33) Gatti, C.; Saunders, V. R.; Roetti, C. J. Chem. Phys. 1994, 101, 10686-10696.

(34) Apra, E.; Causa, M.; Prencipe, M.; Dovesi, R.; Saunders, V. R. J. 
Phys.: Condens. Matter 1993, 5, 2969-2976.

(35) Filinchuk, Y.; Cerny, R.; Hagemann, H. Chem. Mater. 2009, 21, 925-933.

(36) Lee, S. H.; Manga, V. R.; Liu, Z.-K. Int. J. Hydrogen Energy 2010, 35, 6812-6821. 